\title{
GPER1 is regulated by insulin in cancer cells and cancer-associated fibroblasts
}

\author{
Paola De Marco, Enrica Romeo, Adele Vivacqua, Roberta Malaguarnera², \\ Sergio Abonante', Francesco Romeo', Vincenzo Pezzi, Antonino Belfiore ${ }^{2}$ and \\ Marcello Maggiolini \\ Department of Pharmacy, Health and Nutritional Sciences, University of Calabria, 87036 Rende (CS), Italy \\ ${ }^{1}$ Regional Hospital, Cosenza, Italy \\ ${ }^{2}$ Endocrinology, Department of Health, University Magna Graecia of Catanzaro, Catanzaro, Italy
}

Correspondence should be addressed to M Maggiolini

Email

marcellomaggiolini@yahoo.it

\begin{abstract}
Elevated insulin levels have been associated with an increased cancer risk as well as with aggressive and metastatic cancer phenotypes characterized by a poor prognosis. Insulin stimulates the proliferation, migration, and invasiveness of cancer cells through diverse transduction pathways, including estrogen signaling. As $\mathrm{G}$ protein estrogen receptor 1 (GPER1) mediates rapid cell responses to estrogens, we evaluated the potential of insulin to regulate GPER1 expression and function in leiomyosarcoma cancer cells (SKUT-1) and breast cancer-associated fibroblasts (CAFs), which were used as a model system. We found that insulin transactivates the GPER1 promoter sequence and increases the mRNA and protein expression of GPER1 through the activation of the PRKCD/MAPK1/c-Fos/AP1 transduction pathway, as ascertained by means of specific pharmacological inhibitors and gene-silencing experiments. Moreover, cell migration triggered by insulin occurred through GPER 1 and its main target gene CTGF, whereas the insulin-induced expression of GPER1 boosted cell-cycle progression and the glucose uptake stimulated by estrogens. Notably, a positive correlation between insulin serum levels and GPER 1 expression was found in cancer fibroblasts obtained from breast cancer patients. Altogether, our data indicate that GPER 1 may be included among the complex network of transduction signaling triggered by insulin that drives cells toward cancer progression.
\end{abstract}

Key Words

- insulin

- GPER1

- estrogen

- cancer cells

- cancer-associated fibroblasts (CAFs)
Endocrine-Related Cancer (2014) 21, 739-753

\section{Introduction}

Insulin, a key mediator of important metabolic functions, coordinates and regulates the storage and release of the body's fuel (Belfiore \& Malaguarnera 2011). Insulin, which is secreted by $\beta$-cells of the pancreas in response to increasing blood glucose levels, binds to the cognate receptor (INSR) mainly expressed by hepatocytes, adipocytes, and muscle cells as well as prostate and breast tissues
(Belfiore \& Malaguarnera 2011). So far, two INSR isoforms have been identified, isoform A (INSR-A) and isoform B (INSR-B), which are usually co-expressed and regulated by several factors (Belfiore 2007). Expression of INSR-A has been predominantly detected in fetal tissues and tumors as found in leiomyosarcoma cells (Vigneri et al. 2009, Morcavallo et al. 2011). Aside from its important

Published by Bioscientifica Ltd. 
contribution to maintenance of metabolic activity and glucose homeostasis, insulin shows mitogenic potential which can lead to an increased risk of certain types of cancer (Belfiore \& Malaguarnera 2011). Accordingly, it has been suggested that direct INSR stimulation activates diverse transduction mechanisms involved in tumor development (Belfiore \& Malaguarnera 2011). Moreover, in cancer patients affected by insulin resistance, increased insulin levels combine with frequent INSR overexpression in tumor cells, leading to abnormal stimulation of nonmetabolic effects mediated by INSR, such as cell survival, proliferation, and migration (Belfiore \& Malaguarnera 2011). In particular, high insulin levels are associated with an augmented risk of breast cancer and breast cancer relapses in diabetic and nondiabetic women (Duggan et al. 2011, Cohen \& Le Roith 2012, Sieri et al. 2012). It has been well established that a cooperative crosstalk between insulin and estrogen signaling pathways triggers multiple biological events in breast carcinogenesis (Rose \& Vona-Davis 2012, Catsburg et al. 2014). Estrogens mainly act through the classical estrogen receptor $\alpha$ (ESR1) and $\beta$ (ESR2) (Hall et al. 2001), however many effects induced by these steroids are mediated by the $\mathrm{G}$ protein estrogen receptor 1 (GPER1, formerly known as GPR30) in several types of tumor cells and cancer-associated fibroblasts (CAFs), major players in the tumor microenvironment driving tumor progression (Madeo \& Maggiolini 2010, Pupo et al. 2012, Lappano et al . 2013). In this respect, the recent identification of molecules acting as selective agonist or antagonist ligands of GPER1 has allowed the evaluation of the transduction mechanisms involved in the estrogenic GPER1 signaling in numerous pathophysiological conditions (Dennis et al. 2011, Lappano et al. 2012, Rosano et al. 2012). Indeed, GPER1 has been implicated not only in cancer, but also in cardiovascular, immunological, and neurological functions as well as diabetes (Mizukami 2010). GPER1 has been proposed as an interesting therapeutic target in diabetes and pancreatic islet transplantation (Mårtensson et al. 2009, Liu et al. 2013). Accordingly, GPER1 has been detected in pancreatic $\beta$-cells and GPER1 ligands have shown insulinotropic effects by mediating pancreatic $\beta$-cell survival and stimulating insulin release (Liu et al. 2009, Balhuizen et al. 2010). Pharmacological manipulations and gene deletion of Gper1 in mice $\left(\mathrm{Gpr}^{3} 0^{-{ }^{-}}\right)$were associated with an altered insulin release upon estrogen exposure (Mårtensson et al. 2009, Balhuizen et al. 2010). GPER1 deficiency resulted also in insulin resistance, dyslipidemia, obesity, and increased circulating pro-inflammatory cytokines, indicating a role for GPER1 in the regulation of metabolism and the inflammatory state (Sharma et al. 2013).
As regards the regulation of GPER1, our previous studies have shown that some important growth-factormediated transduction pathways such as EGFR (Albanito et al. 2008, Vivacqua et al. 2009) and IGF1 (Bartella et al. 2012, De Marco et al. 2013) are involved in the expression and function of GPER1 in cancer cells. Interestingly, high levels of expression of GPER1 in breast, endometrial, and ovarian tumors have been associated with a higher risk of developing metastatic disease and poor survival (Prossnitz \& Barton 2011). Moreover, high levels of GPER1 were identified in inflammatory breast cancer (IBC), an aggressive and commonly hormone-independent form of breast cancer (Arias-Pulido et al. 2010). Recently, the overexpression of GPER1 and its plasma membrane localization have been suggested to be critical events in breast cancer progression, whereas the lack of GPER1 in the plasma membrane was associated with excellent longterm prognosis in ESR1-positive (Sjöström et al. 2014) tamoxifen-treated breast cancer.

In this study, we ascertained the capability of insulin in regulating GPER1 expression and activity in INSRpositive CAFs and SKUT-1 leiomyosarcoma cells, which were used as model systems. In particular, our results reveal that insulin up-regulates GPER1 by the activation of the PRKCD/MAPK1/c-Fos/AP1 transduction pathway. In addition, GPER1 and its target gene CTGF were required for insulin-induced cell migration. Also, the up-regulation of GPER1 by insulin boosted the glucose uptake and cellcycle progression upon estrogen exposure. Interestingly, a significant positive correlation between GPER1 expression and serum insulin levels have been found in CAFs obtained from breast cancer patients. Our data provide novel insights into the functional crosstalk between GPER1 signaling and the insulin-mediated transduction pathway, highlighting the potential of GPER1 to contribute to cancer progression in patients with elevated insulin levels.

\section{Materials and methods}

\section{Reagents}

Bovine insulin and $17 \beta$-estradiol $\left(\mathrm{E}_{2}\right)$ were purchased from Sigma-Aldrich Corp. Bisindolylmaleimide I (GF109203X), PD98059 (PD), Rottlerin, and Tyrphostin AG1478 were bought from Calbiochem (Milan, Italy). ICI 182780 (ICI) and (3aS,4R,9bR)-4-(6-bromo-1,3-benzodioxol-5-yl)3a, 4,5,9b-3H-cyclopenta[c]quinolone (G15) were obtained from Tocris Bioscience (Bristol, UK). Insulin was solubilized in HEPES $25 \mathrm{mM}$. PD and $\mathrm{E}_{2}$ were dissolved

Published by Bioscientifica Ltd. 
in ethanol, while GFX, Rottlerin, and AG were solubilized in dimethylsulfoxide.

\section{Cell culture}

$\mathrm{R}^{-}$mouse fibroblasts (kindly provided by Renato Baserga, Philadelphia, PA, USA) are mouse 3T3-like cells derived from animals with a targeted disruption of the IgfIr gene. $\mathrm{R}^{-}$cells, which express low levels of endogenous INSR (approximately $5 \times 10^{3}$ receptors per cell) (Sell et al. 1994), were cotransfected with the pNTK2 expression vector containing the cDNA for the human INSR-A (Ex11 ${ }^{-}$) or INSR-B (EX $11^{+}$) and with the pPDV61 plasmid encoding the puromicin resistance gene, by using the Lipofectamine reagent (Life Technologies, Inc./BRL, Bethesda, MD, USA), as described previously (Yamada et al. 2007). The cell clones obtained ( $\mathrm{R}^{-} /$INSR-A and $\mathrm{R}^{-}$/INSR-B cells) express approximately $3 \times 10^{5}$ to $5 \times 10^{5}$ receptors per cell (Frasca et al. 1999). All cell types were grown in DMEM ( $4.5 \mathrm{~g} / \mathrm{l}$ glucose) supplemented with $10 \%$ fetal bovine serum (FBS), $1 \%$ penicillin-streptomycin, and $2 \mu \mathrm{g} / \mathrm{ml}$ of puromycin. Leiomyosarcoma SKUT-1 cells were kindly provided by Dr Colombatti (Aviano, Italy). The cells were grown in DMEM supplemented with $10 \%$ FBS and $1 \mathrm{mM}$ Na pyruvate. CAFs were obtained from surgical specimens of breast cancer tissues from 47 patients who underwent mastectomy at the Regional Hospital in Cosenza (Italy). The samples were immediately incised in $5 \mathrm{ml}$ of medium and incubated overnight in digestion solution (400 IU collagenase, 100 IU hyaluronidase, and 10\% FBS, containing antibiotic and antimycotic solutions). The cells were then separated by differential centrifugation at $90 \boldsymbol{g}$ for $2 \mathrm{~min}$. The supernatants containing fibroblasts were centrifuged at $485 \mathrm{~g}$ for $8 \mathrm{~min}$, the pellets obtained were suspended in fibroblasts growth medium (Medium 199 and Ham's F12 mixed 1:1 and supplemented with 10\% FBS and $1 \%$ penicillin) and cultured at $37{ }^{\circ} \mathrm{C}$ and $5 \% \mathrm{CO}_{2}$. At $80 \%$ of confluence, the fibroblasts were stored at $-80^{\circ} \mathrm{C}$ for the next isolation of RNA. Primary cell cultures of breast fibroblasts were characterized by immunofluorescence. Briefly, cells were incubated with human anti-vimentin (V9) and human anti-cytokeratin 14 (LL001) (Santa Cruz Biotechnology, DBA). In order to assess fibroblast activation, anti-fibroblast-activated protein $\alpha(\mathrm{FAP} \alpha)$ antibody (H-56, Santa Cruz Biotechnology, DBA) was used. All experiments were carried out in a mixed population of CAFs obtained from five patients with low serum insulin levels. Signed informed consent from all the patients was obtained and all samples were collected, identified, and used in accordance with the approval by the Institutional Ethical Committee Board (Regional Hospital of Cosenza, Italy).

\section{Plasmids}

The plasmid DN/c-Fos, which encodes a c-Fos mutant that heterodimerizes with c-Fos dimerization partners but does not allow DNA binding, was a kind gift from Dr C Vinson (NIH, Bethesda, MD, USA). Short hairpin constructs against human GPER1 (shGPER1) and CTGF (shCTGF) were generated and used as described previously (Albanito et al. 2008). In brief, they were generated in the lentiviral expression vector pLKO.1 purchased from Euroclone, Milan, Italy. The targeting strand generated from the shGPER1 construct is $5^{\prime}$-CGCTCCCTGCAAGCAGTCTTT$3^{\prime}$. The targeting strand generated from the shCTGF construct is $5^{\prime}$-TAGTACAGCGATTCAAAGATG- ${ }^{\prime}$. The shINSR was purchased from SABiosciences (Qiagen).

\section{Transfections and luciferase assays}

The cells $\left(1 \times 10^{5}\right)$ were plated into 24 -well dishes with $500 \mu \mathrm{l} /$ well of regular growth medium the day before transfection. The medium was replaced with DMEM, lacking serum and phenol red on the day of transfection, which was performed using X-tremeGene9 reagent, as recommended by the manufacturer (Roche Molecular Biochemical), with a mixture containing $0.5 \mathrm{mg}$ of reporter plasmid and $2 \mathrm{ng}$ of pRL-TK. After $6 \mathrm{~h}$, the medium was replaced again with DMEM, lacking serum and phenol red, treatments were added and the cells were incubated for an additional $24 \mathrm{~h}$. Luciferase activity was then measured with the Dual Luciferase Kit (Promega Italia) according to the manufacturer's recommendations. Firefly luciferase activity was normalized to the internal transfection control provided by the Renilla luciferase activity. The normalized relative light unit values obtained from cells treated with vehicle were defined as onefold induction, relative to which the activity induced by treatments was calculated.

\section{RT and real-time PCR}

Total RNA was extracted using the Trizol Commercial Kit (Invitrogen) according to the manufacturer's protocol. RNA was quantified spectrophotometrically, and its quality was checked by electrophoresis through agarose gels stained with ethidium bromide. Total cDNA was synthesized from RNA by RT using the murine leukemia virus reverse transcriptase (Invitrogen) following the protocol provided by the manufacturer. The expression of selected genes was quantified by real-time PCR using the Step One (TM) sequence detection system (Applied

Published by Bioscientifica Ltd. 
Biosystems, Inc.), following the manufacturer's instructions. Gene-specific primers were designed using Primer Express version 2.0 software (Applied Biosystems, Inc.). The assays were carried out in triplicate, and the mean values were used to calculate expression levels, using the relative standard curve method. For GPER1 (mouse) the primers used were: $5^{\prime}$-TGGTGGTGAACATCAGTCTC- $3^{\prime}$ (GPER1 forward); 5'-AAGCTCATCCAGCTGAGGAA-3'. For GPER1 (human) the primers used were: 5'-ACACACCTGGGTGGACACAA-3' (GPER1 forward); 5'GGAGCCAGAAGCCACATCTG-3' (GPER1 reverse). For the ribosomal protein $18 \mathrm{~S}$ (human and mouse), which was used as a control gene to obtain normalized values, the primers used were: $5^{\prime}$-GGCGTCCCCCAACTTCTTA-3' (18S forward) and 5-GGGCATCACAGACCTGTTATT-3' (18S reverse). The assays were carried out in triplicate and the results were normalized for $18 \mathrm{~S}$ expression and then calculated as fold induction of RNA expression. To quantify the GPER1 expression in CAFs obtained from breast cancer patients, standard curve was generated using serially diluted solutions of cDNA from a mixture of all samples. $5 \mu \mathrm{l}$ cDNA of each sample were mixed to obtain the solution of the standard stock (tube 1, first dilution point), which was used to prepare the other four dilution points. Each dilution point (in triplicate) was added into well plates containing the Master Mix solution and, according to the protocol of the real-time software, the concentration of each solution $(\mathrm{ng} / \mathrm{ml})$ was recorded. The absolute quantification of unknown values was obtained by interpolating the PCR signals into the standard curve provided by the serially diluted solutions. PCR amplification was carried out in duplicate for each sample and the results are expressed as mean values. The content of GPER1 transcript was normalized to the content of the housekeeping gene18S.

\section{Western blotting}

The cells were grown in 10-cm dishes and exposed to ligands before lysis in $500 \mu \mathrm{l}$ of lysis buffer containing the following: $50 \mathrm{mM}$ HEPES pH 7.5, $150 \mathrm{mM} \mathrm{NaCl}, 1.5 \mathrm{mM}$ $\mathrm{MgCl}_{2}, 1 \mathrm{mM}$ EGTA, 10\% glycerol, 1\% Triton X-100, 1\% SDS, and a mixture of protease inhibitors (Aprotinin, PMSF, and Na-orthovanadate). Protein concentrations were determined according to the Bradford method (Sigma-Aldrich). Equal amount of whole protein extracts were electrophoresed through a reducing SDS/10\% (w/v) polyacrilamide gel and transferred to a nitrocellulose membrane (Amersham Biosciences). The membranes were blocked and probed with primary antibodies against
GPER1 (N-15), CTGF (L-20), c-Fos (H-125), phosphorylated MAPK1/2 (E-4), MAPK2 (C-14), phosphorylated PRKCD (Thr 507), PRKCD (C-20), $\beta$-actin (C2), and $\beta$-tubulin (sc-9104) purchased from Santa Cruz Biotechnology (DBA); insulin receptor $\alpha$ (INSR $\alpha$ ) from BD Bioscience (Milan, Italy). The levels of protein and phosphoproteins were detected with appropriate secondary HRP-conjugated antibodies and the ECL System (GE Healthcare, Milan, Italy). All experiments were carried out in triplicate and blots shown are representative.

\section{Chromatin immunoprecipitation}

The cells grown on 10-cm plates were shifted and treated for $24 \mathrm{~h}$ in a medium lacking serum and then with vehicle or insulin $(10 \mathrm{nM})$. Chromatin immunoprecipitation (Chip) assay was carried out as described previously (De Marco et al. 2013). The immune-cleared chromatin was immunoprecipitated with anti c-Fos (H-125) or nonspecific IgG (Santa Cruz Biotechnology, DBA). A $4 \mu \mathrm{l}$ volume of each immunoprecipitated DNA sample and input were used as a template to amplify by PCR the region containing an AP- 1 site located in the GPER1 promoter region. The primers used to amplify this fragment were as follows: $5^{\prime}$ CGTGCCCATACCTTCATTGCTTCC-3' (forward) and 5'-CCTGGCCGGGTGTCTGTG-3' (reverse).

\section{Immunostaining assay}

Fifty percent confluent, cultured, CAFs and leiomyosarcoma SKUT-1 cells grown on coverslips were serum deprived and transfected for $12 \mathrm{~h}$ with a control shRNA or a shRNA specific for GPER1 (shGPER1), using X-tremeGene9 reagent (Roche Molecular Biochemical), as recommended by the manufacturer, and then treated for $24 \mathrm{~h}$ with vehicle or $10 \mathrm{nM}$ insulin. Thereafter, the cells were fixed in $4 \%$ paraformaldehyde, permeabilized with $0.2 \%$ TritonX-100, washed three times with PBS and blocked and incubated overnight with primary antibody human GPER1 (N-15). After incubation, the slides were extensively washed with PBS and incubated with donkey anti-rabbit IgG-FITC (1:500, from Santa Cruz Biotechnology) and propidium iodide (1:1000, Sigma-Aldrich). A Leica AF6000 Advanced Fluorescence Imaging System supported by the quantification and image processing software Leica Application Suite Advanced Fluorescence (Leica Microsystems CMS, GbH Mannheim, Germany) were used for evaluation of experiments.

Published by Bioscientifica Ltd. 


\section{Migration assay}

Migration assays were carried out using Boyden Chambers (Costar Transwell, $8 \mathrm{~mm}$ polycarbonate membrane). For knockdown experiments, the cells were transfected with shRNA constructs directed against GPER1 or CTGF and with an unrelated shRNA construct (500 ng DNA/well transfected with $\mathrm{X}$-tremeGene9 reagent in the medium without serum). After $24 \mathrm{~h}$, the cells were seeded into the upper chambers.

\section{Glucose uptake assay}

The fluorescent analog of glucose 2-(N-(7 nitrobenz-2oxa-1,3-diazol-4-yl)amino)-2-deoxy-D-glucose (2-NBDG; Life Technologies) was used to measure glucose uptake. Around $1 \times 10^{5}$ cells per well were seeded into 12 -well plates and maintained in the medium for $24 \mathrm{~h}$. For knockdown experiments, the cells were transfected for $48 \mathrm{~h}$ with shRNA constructs directed against GPER1 and with an unrelated shRNA construct (3 $\mu \mathrm{g}$ DNA/well transfected with $\mathrm{X}$-tremeGene9 reagent in medium without serum). Subsequently, the fluorescence was measured using an FLX-800 micro plate fluorimeter (Bio-Tek Instruments, Inc., Winooski, VT, USA) with an excitation wavelength of $465 \mathrm{~nm}$ and an emission wavelength of $540 \mathrm{~nm}$ (Yamada et al. 2007).

\section{Cell-cycle analysis}

Around $1 \times 10^{5}$ cells per well were seeded into 12 -well plates and maintained in the medium for $24 \mathrm{~h}$. For knockdown experiments, the cells were transfected for $48 \mathrm{~h}$ with shRNA constructs directed against GPER1 and with an unrelated shRNA construct (3 $\mu \mathrm{g}$ DNA/well transfected with $\mathrm{X}$-tremeGene9 reagent in medium without serum). The cells were then treated with $10 \mathrm{nM}$ insulin for $8 \mathrm{~h}$, thereafter the medium was removed and replaced

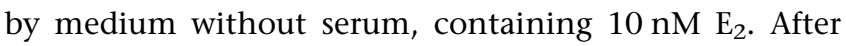
$8 \mathrm{~h}$, the cells were pelleted, washed once with PBS, and resuspended in $0.5 \mathrm{ml}$ of a $50 \mu \mathrm{g} / \mathrm{ml}$ propidium iodide in $1 \times$ PBS $(\mathrm{PI})$ solution containing $20 \mathrm{U} / \mathrm{ml}$ RNAse-A and $0.1 \%$ triton and incubated for $1 \mathrm{~h}$ (Sigma-Aldrich). The cells were analyzed for DNA content by fluorescenceactivated cell sorting (BD, FACS JAZZ). The cell phases were estimated as a percentage of a total of 10000 events.

\section{Immunohistochemistry}

Immediately after excision, the tissue samples were fixed in $10 \%$ buffered formaldehyde solution and embedded in paraffin wax blocks at $56^{\circ} \mathrm{C}$. GPER1 was analyzed by immunohistochemical (IHC) staining using $3 \mu \mathrm{m}$ thick consecutive paraffin sections. The sections were dewaxed in xylene and rehydrated in graded alcohols. Antigen retrieval was achieved by boiling in $0.01 \mathrm{M}$ citrate buffer of $\mathrm{pH}$ 6. Endogenous peroxidase was removed with $3 \% \mathrm{H}_{2} \mathrm{O}_{2}$; nonspecific binding was blocked by incubating the slides for 30 min with $1.5 \%$ BSA in PBS. Next, the sections were incubated with the primary antibodies for $1 \mathrm{~h}$ at room temperature. GPER1 was detected using GPER1 mouse MAb (DakoCytomation, Glostrup, Denmark) at dilution 1:100. Ab-antigen reactions were revealed using a streptavidin-biotinperoxidase complex (LSAB kit, DakoCytomation). All slides were counterstained with hematoxylin. Breast specimens previously classified as positive for the expression of the studied markers were used for control and protocol standardization. In negative controls, primary antibodies were omitted. The expression of GPER1 was independently scored by two investigators by light microscopy of ten different section fields.

\section{Statistical analysis}

Statistical analysis was performed using ANOVA followed by Newman-Keuls' testing to determine differences in means. $P<0.05$ was considered as statistically significant. Relationships between variables were assessed with the Spearman's correlation coefficient. Differences and relationships were considered statistically significant when $P<0.05$.

\section{Results}

\section{Insulin induces GPER1 expression}

On the basis of previous data, showing that a functional cross-talk may occur between GPER1 and insulinmediated action (Sharma et al. 2013), we aimed to evaluate whether insulin could regulate GPER1 expression and function. As shown in Fig. 1A, we first ascertained that insulin transactivates a GPER1 promoter construct, which was transiently transfected into mouse fibroblasts expressing only INSR-A or INSR-B but not IGF1R ( ${ }^{-} /$INSR-A and $\mathrm{R}^{-}$/INSR-B cells respectively) (Pandini et al. 2002), in breast CAFs that express both INSR isoforms (data not shown) and in leiomyosarcoma cells (SKUT-1) that express almost only INSR-A (Sciacca et al. 2002). In accordance with these findings, insulin upregulated the mRNA (Fig. 1B) and protein levels of GPER1 in all cells used (Fig. 2A, B, C, D, and E), except for the mouse fibroblasts that lack IGF1R $\left(\mathrm{R}^{-}\right)$and express low endogenous INSR

Published by Bioscientifica Ltd 

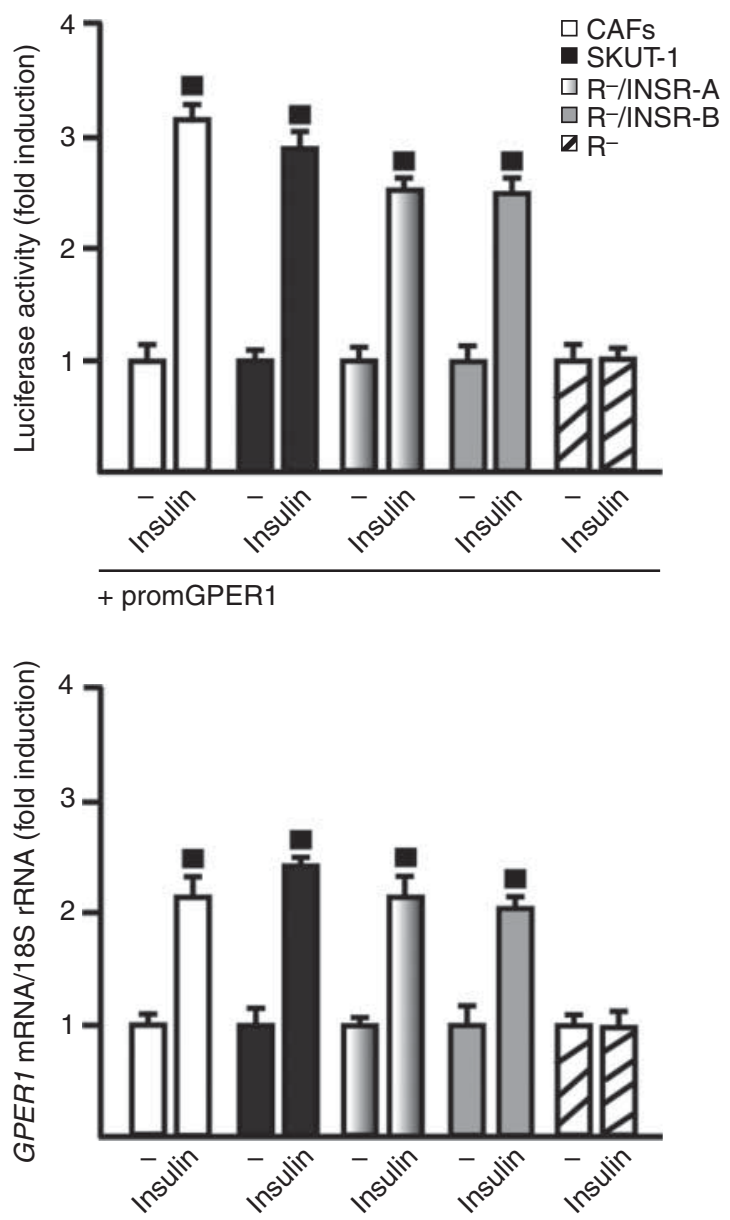

Figure 1

(A) $10 \mathrm{nM}$ insulin induces the transactivation of the GPER1 promoter construct only in mouse fibroblasts expressing insulin receptor isoform $A$ ( $\mathrm{R}^{-} /$INSR-A) or isoform $B$ ( $\mathrm{R}^{-} /$INSR-B), in cancer-associated fibroblasts (CAFs) and leiomyosarcoma SKUT-1 cells. The luciferase activities were normalized to the internal transfection control and values of cells receiving vehicle $(-)$ were defined as onefold induction, relative to which the activities induced by insulin were calculated. (B) A $4 \mathrm{~h}$ treatment with $10 \mathrm{nM}$ insulin upregulated GPER1 mRNA expression only in $\mathrm{R}^{-}$/INSR-A, $\mathrm{R}^{-}$/INSR-B, CAFs, and SKUT-1 cells, as evaluated by real-time PCR. The mRNA expression of GPER1 was normalized to (18S) expression. Each column represents the mean \pm s.D. of three independent experiments carried out in triplicate. (closed square) $P<0.05$ for cells receiving vehicle (-) vs treatments.

levels (Sciacca et al. 2002). Further corroborating these results, the upregulation of GPER1 protein levels by insulin was no longer evident after silencing of INSR expression in CAFs and SKUT-1 cells (Fig. 2F and I). Results from immunofluorescence studies on CAFs and SKUT-1 cells transfected with a shGPER1 indicated that insulininduced GPER1 expression was abolished, confirming the aforementioned observations (Fig. 3). Next, the induction of GPER1 protein by insulin was prevented by using the PRKC inhibitor GF109203X (GF), the MEK inhibitor
PD98059 (PD), and the PRKCD inhibitor Rottlerin (Rot), but still persisted in presence of the EGFR inhibitor AG1478 (AG) (Fig. 4A, B, C, and D). It is concluded that, insulin induced PRKCD and MAPK1 activation in $\mathrm{R}^{-}$/INSR-A, $\mathrm{R}^{-}$/INSR-B, CAFs, and SKUT- 1 cells, but not in $\mathrm{R}^{-}$cells (Supplementary Figure 1 , see section on supplementary data given at the end of this article).

\section{GPER1 upregulation by insulin involves activation of c-Fos/AP1 transcription}

It has been previously shown that the activation of MAPK1 transduction pathway leads to a rapid induction of c-Fos (Maggiolini et al. 2004, Vivacqua et al. 2006a,b, Albanito et al. 2007), which has a growth stimulatory role in normal and cancer cells mainly activating the AP1 transcription complex together with Jun family members (Hess et al. 2004). In line with these data, in both CAFs and SKUT-1 cells, insulin induced the expression of c-Fos (Fig. 5A and B), which was recruited to the AP1 site located within the promoter sequence of GPER1, as ascertained by CHIP assay (Fig. 5C and D). Confirming these findings, insulin transactivated an $A P 1$ promoter construct transfected into CAFs and SKUT-1 cells; however, the luciferase activity was abrogated by co-transfecting an expression vector encoding a dominant-negative form of c-Fos (DN/c-Fos) (Fig. 5E and F). Likewise, the transactivation of the GPER1 promoter construct (Fig. 5G and $\mathrm{H}$ ) as well as the upregulation of GPER1 protein levels (Fig. 5I and J) were prevented in the presence of the DN/c-Fos. Taken together, our results indicate that insulin upregulates GPER1 expression through INSR-A and INSR-B along with the activation of PRKCD/MAPK1/c-Fos/AP1 transduction pathway.

\section{GPER1 mediates CTGF expression and cell migration induced by insulin}

Next, we sought to evaluate whether the insulin-induced GPER1 expression could be followed by the upregulation of a main GPER1 target gene, CTGF (Pandey et al. 2009). Noteworthily, insulin triggered CTGF protein induction in $\mathrm{R}^{-} /$INSR-A, $\mathrm{R}^{-}$/INSR-B, CAFs, and SKUT-1 cells (Fig. 6A, B, $\mathrm{C}$, and $\mathrm{D}$ ). In the last two cell types, the increase in CTGF protein levels was abolished by silencing INSR and GPER1 expression as well as transfecting cells with the DN/c-Fos plasmid (Fig. 7A, B, C, D, E, F, G, H, I, and J). As a biological counterpart, the migration stimulated by insulin in CAFs and SKUT-1 was prevented by treatment with the GPER1 antagonist G15 (Supplementary Figure 2, see section on supplementary data given at the end of this article), as well

Published by Bioscientifica Ltd. 

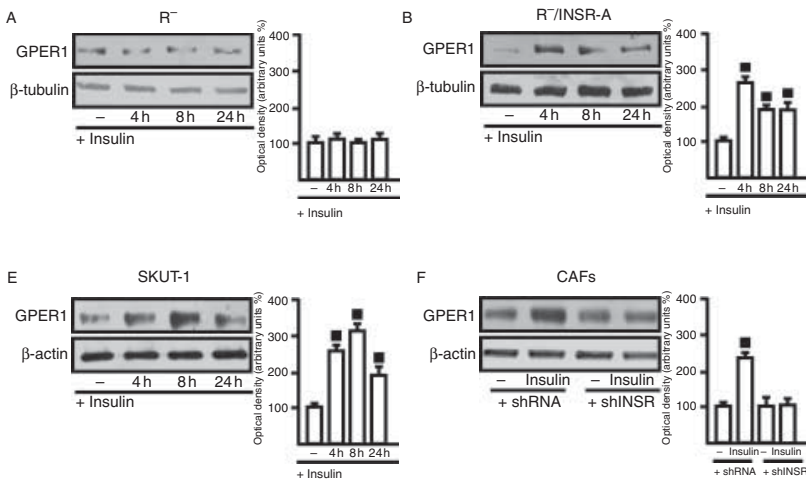

$\beta$


Figure 2

$(\mathrm{A}, \mathrm{B}, \mathrm{C}, \mathrm{D}$, and $\mathrm{E})$ Treatment with $10 \mathrm{nM}$ insulin induces increases in the GPER1 protein levels only in $\mathrm{R}^{-}$/INSR-A or $\mathrm{R}^{-}$/INSR-B, CAFs, and SKUT-1 cells. (F, G, H, and I) In CAFs and SKUT-1 cells transfected with a shINSR, treatment for $8 \mathrm{~h}$ with $10 \mathrm{nM}$ insulin does not trigger an increase in GPER1

as transfecting cells with the shGPER1 or shCTGF constructs (Fig. 7K, L, M, N, O, and P), while the ER antagonist ICI did not have any inhibitory effect (Supplementary Figure 2). Taken together, these results indicate that GPER1 is involved in the upregulation of CTGF, and that both GPER1 and CTGF are required for the migratory effects stimulated by insulin.
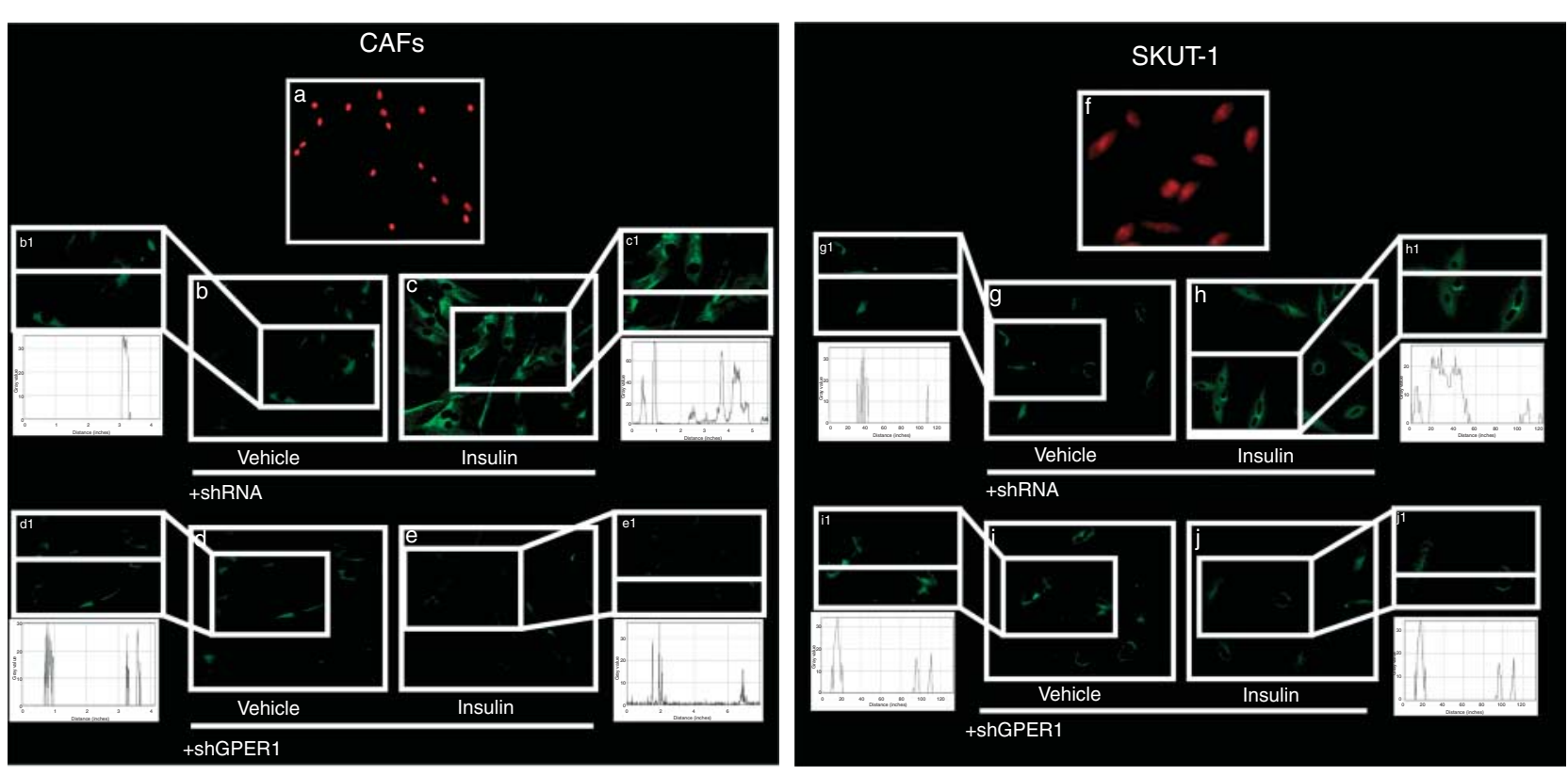

Figure 3

CAFs and SKUT-1 cells were fixed, permeabilized, and stained with anti-GPER1 antibody. Nuclei (red) were stained with propidium iodide ( $a$ and $f$ ). The cells were transfected with a control shRNA ( $b, c$ and $g, h$ ) or with a shGPER1 ( $d$, e and $\mathrm{i}, \mathrm{j}$ ) and treated for $8 \mathrm{~h}$ with vehicle $(-)$ or $10 \mathrm{nM}$ insulin and then stained with the GPER1 antibody. For descriptive purposes, panels b1, c1, d1, e1, g1, h1, i1 and j1 show the plot profiles protein levels. The charts show results of densitometric analysis of the blots normalized to $\beta$-tubulin or $\beta$-actin levels. Each column represents the mean \pm s.D. of three independent experiments. (closed square) $P<0.05$ for cells receiving vehicle $(-)$ vs treatments.

\section{GPER1 is involved in the glucose uptake and cell-cycle progression stimulated by insulin}

Recently, estrogens have been reported to increase glucose uptake in breast cancer cells through a mechanism which involves ESR1 (Garrido et al. 2013). As GPER1 mediates estrogen signaling (Maggiolini \& Picard 2010) and

obtained at the level of white lines of the corresponding insets, as calculated by using the program WCIF Image J for Windows. Note the higher values indicating zones of intense labeling. Each experiment shown is representative of ten random fields. Data are representative of three independent experiments.

Published by Bioscientifica Ltd. 

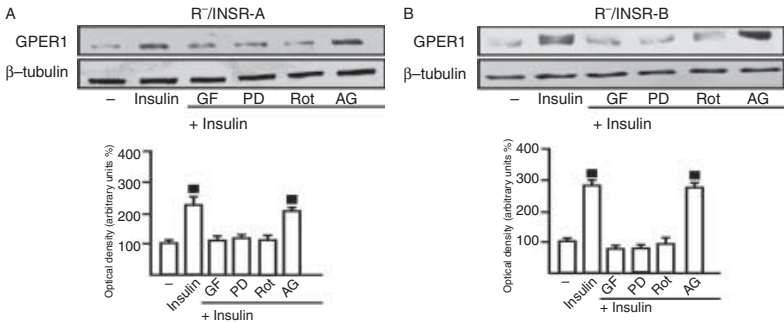

Figure 4

(A, B, C, and D) GPER1 protein expression evaluated in $\mathrm{R}^{-} /$INSR-A or $\mathrm{R}^{-} /$INSR$B$, CAFs and SKUT-1 cells treated for $4 \mathrm{~h}$ with vehicle $(-)$ or $10 \mathrm{nM}$ insulin alone and in combination with $10 \mu \mathrm{M}$ PRKC inhibitor GF109203X(GF), $10 \mu \mathrm{M}$ MEK inhibitor PD98059 (PD), $10 \mu \mathrm{M}$ PRKCD inhibitor Rottlerin (Rot), and

contributes to certain metabolic responses to insulin (Liu et al. 2009, Balhuizen et al. 2010, Sharma et al. 2013), we investigated whether glucose uptake could be stimulated by estrogens through GPER1. Moreover, before
C
GPER1
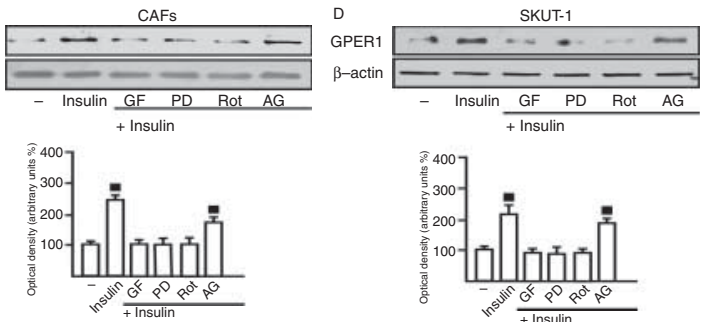

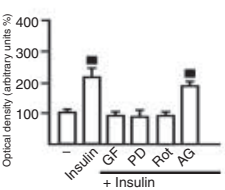

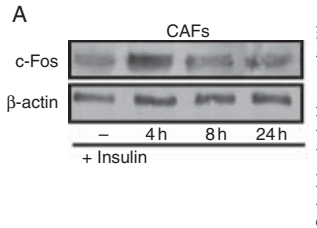
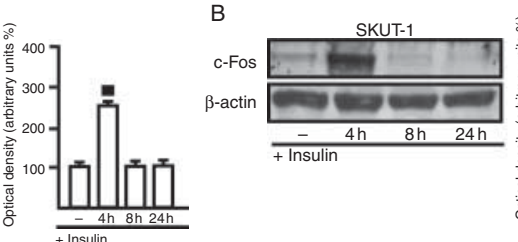

$E$
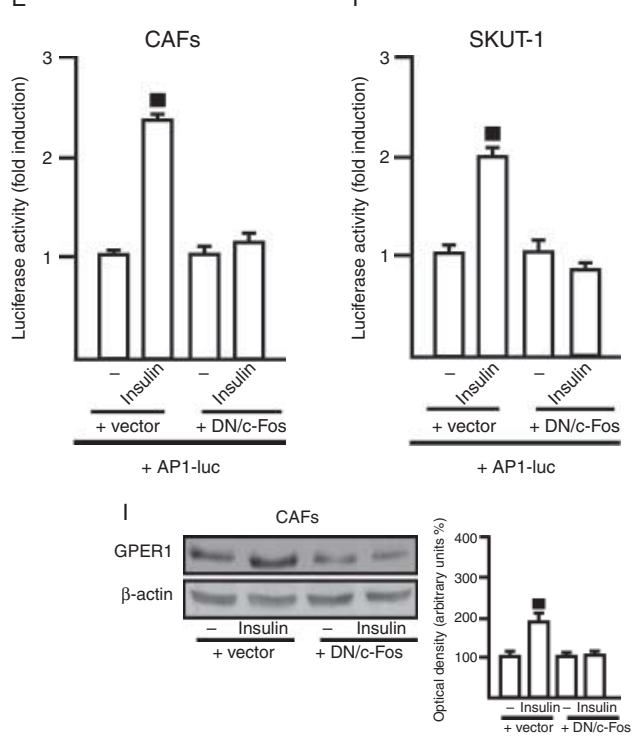

$10 \mu \mathrm{M}$ EGFR inhibitor AG1478 (AG). The charts show the results of densitometric analysis of the blots normalized to $\beta$-tubulin or $\beta$-actin. Each column represents the mean \pm s.D. of three independent experiments.

(closed square) Indicates $P<0.05$ for cells receiving vehicle $(-$ ) vs treatments.

exposure to estrogens, the cells were also treated with insulin, which upregulates GPER1 expression, as demonstrated above. Interestingly, the glucose uptake stimulated by $\mathrm{E}_{2}$ was further boosted in CAFs and SKUT-1 cells


G

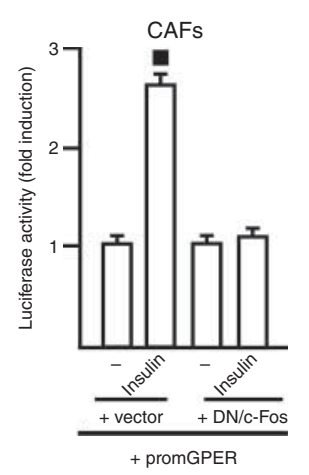

$\mathrm{H}$
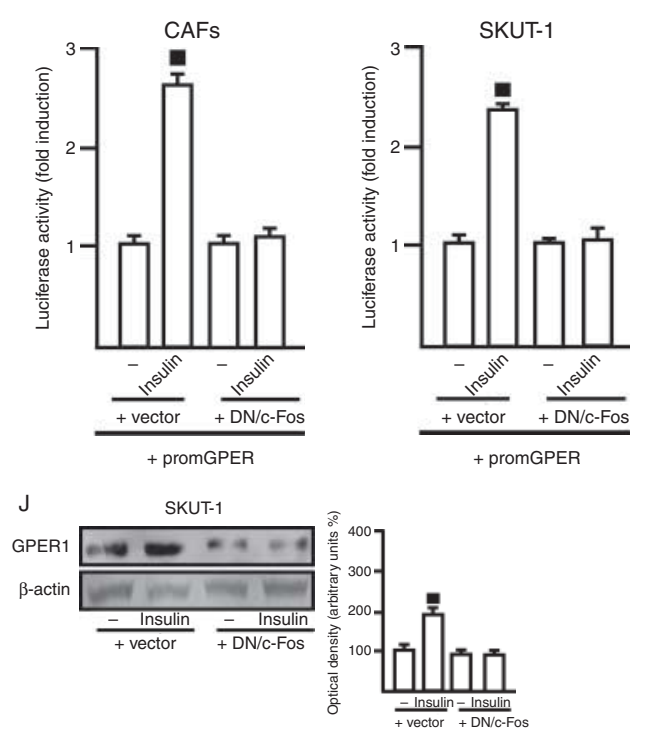

\section{Figure 5}

In CAFs and SKUT-1 cells, $10 \mathrm{nM}$ insulin induced the expression of c-Fos ( $A$ and $B$ ), which is recruited to the AP1 site located within the GPER1 promoter sequence by a $4 \mathrm{~h}$ treatment with $10 \mathrm{nM}$ insulin ( $C$ and $D$ ). The transactivation of an AP1-LUC reporter gene (E and F) and the GPER1 promoter construct ( $\mathrm{G}$ and $\mathrm{H}$ ) induced by a $18 \mathrm{~h}$ treatment with $10 \mathrm{nM}$ insulin as well as the GPER 1 protein increase induced by a $4 \mathrm{~h}$ treatment with $10 \mathrm{nM}$ insulin were prevented in the presence of a dominant negative form of c-Fos construct (DN/C-Fos). (I and J) Each transfection experiment was performed in triplicate, the luciferase activities from three independent experiments were normalized to the internal transfection control and values for cells receiving vehicle $(-)$ were defined as onefold induction relative to which the activities induced by insulin were calculated. In immunoblotting, the charts show results of densitometric analysis of the blots normalized to $\beta$-tubulin or $\beta$-actin and each column represents the mean \pm s.D. of three independent experiments. (closed square) $P<0.05$ for cells receiving vehicle $(-)$ vs treatments.

Published by Bioscientifica Ltd. 
A



B

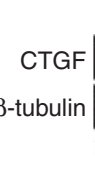

$\mathrm{R}^{-} /$INSR-B
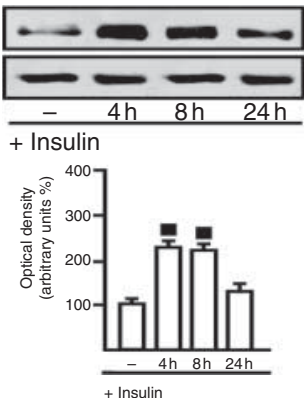

Figure 6

( $A, B, C$, and $D$ ) CTGF protein expression is upregulated by $10 \mathrm{nM}$ insulin in $\mathrm{R}^{-}$/INSR-A and $\mathrm{R}^{-}$/INSR-B, CAFs, and SKUT- 1 cells. The charts show the results from densitometric analysis of the blots normalized to $\beta$-tubulin or

treated with insulin before the treatment with $\mathrm{E}_{2}$, as assessed by fluorescence assays (Fig. 8A and B). The glucose uptake induced by $\mathrm{E}_{2}$ alone and the additional stimulation obtained by insulin were prevented by silencing of GPER1 expression (Fig. 8A and B) and by use of the GPER1 antagonist G15, but not in the presence of the ER

C

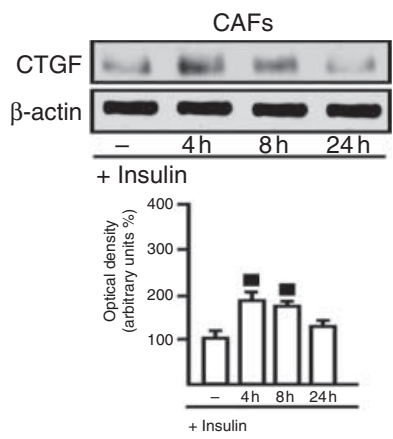

D
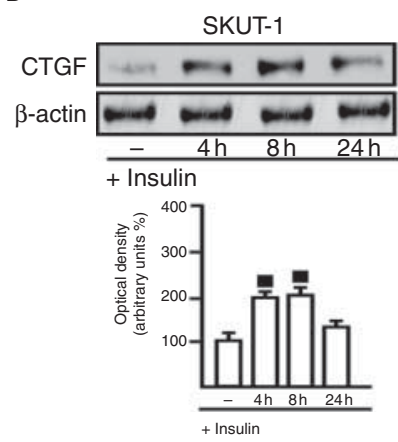

$\beta$-actin. Each column represents the mean \pm s.D. of three independent experiments. (closed square) Indicates $P<0.05$ for cells receiving vehicle ( ) vs treatments.

inhibitor ICI (Supplementary Figure 3, see section on supplementary data given at the end of this article). By silencing GPER1 expression, we then ascertained that GPER1 mediates both the $E_{2}$-induced increase in the percentage of CAFs and SKUT-1 cells in the G2/M phase and the further boost observed from treating cells with
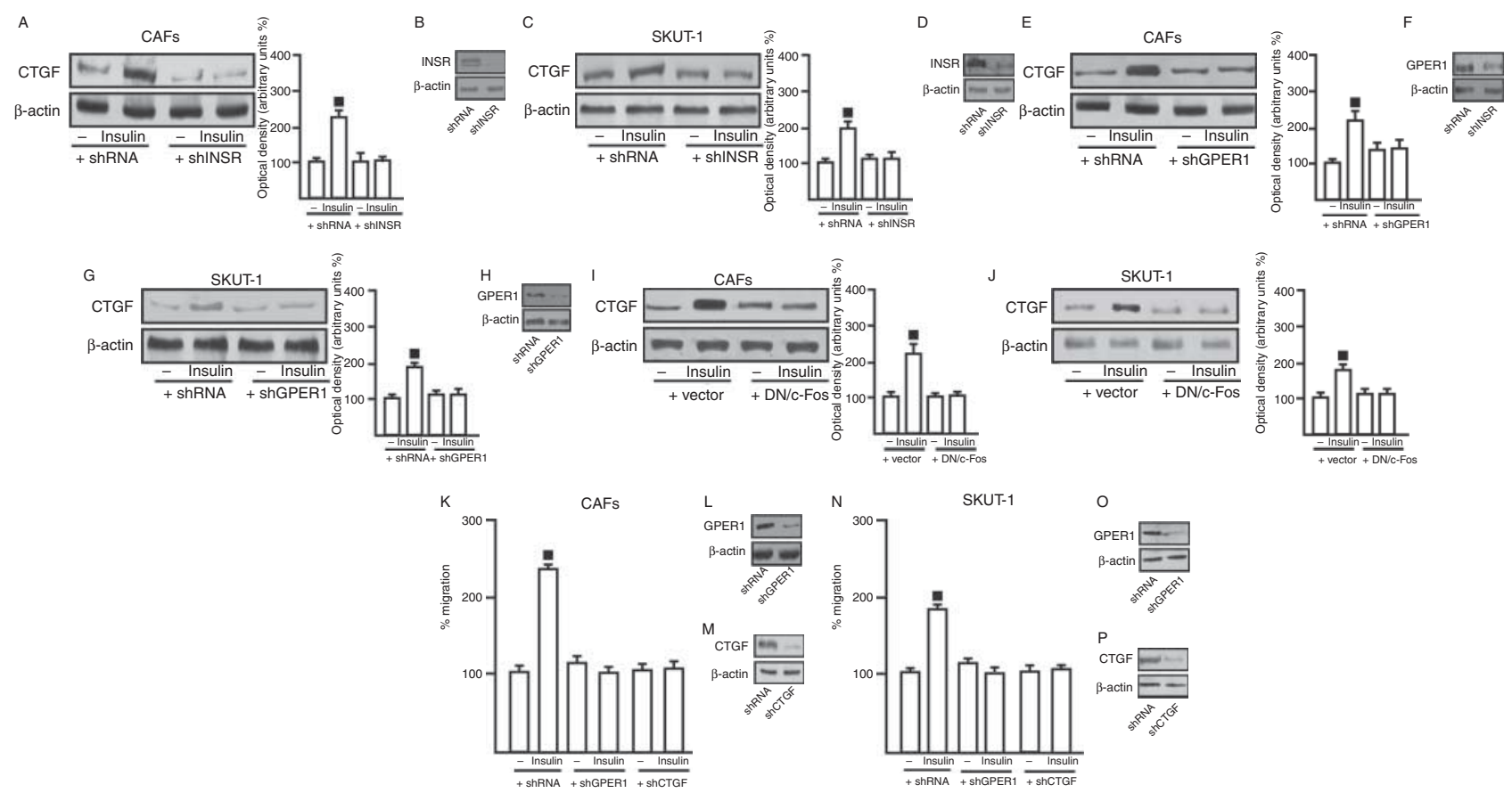

\section{Figure 7}

The upregulation of CTGF protein levels induced by a $4 \mathrm{~h}$ treatment with $10 \mathrm{nM}$ insulin was abolished by transfecting CAFs and SKUT-1 cells with shINSR ( $A, B, C$, and D), shGPER1 (E, F, G, and H), or a dominant negative form of C-Fos (DN/C-Fos) (I and J). The migration of CAFs and SKUT-1 cells after a $6 \mathrm{~h}$ treatment with $10 \mathrm{nM}$ insulin was prevented by silencing GPER 1 and CTGF expression ( $\mathrm{K}, \mathrm{L}, \mathrm{M}, \mathrm{N}, \mathrm{O}$, and $\mathrm{P}$ ). Results shown are representative of three independent experiments. The charts show the results from densitometric analysis of the blots normalized to $\beta$-actin. (closed square) $P<0.05$ for cells receiving vehicle $(-)$ vs treatments. http://erc.endocrinology-journals.org DOI: 10.1530/ERC-14-0245 (c) 2014 Society for Endocrinology Printed in Great Britain 
A CAFs
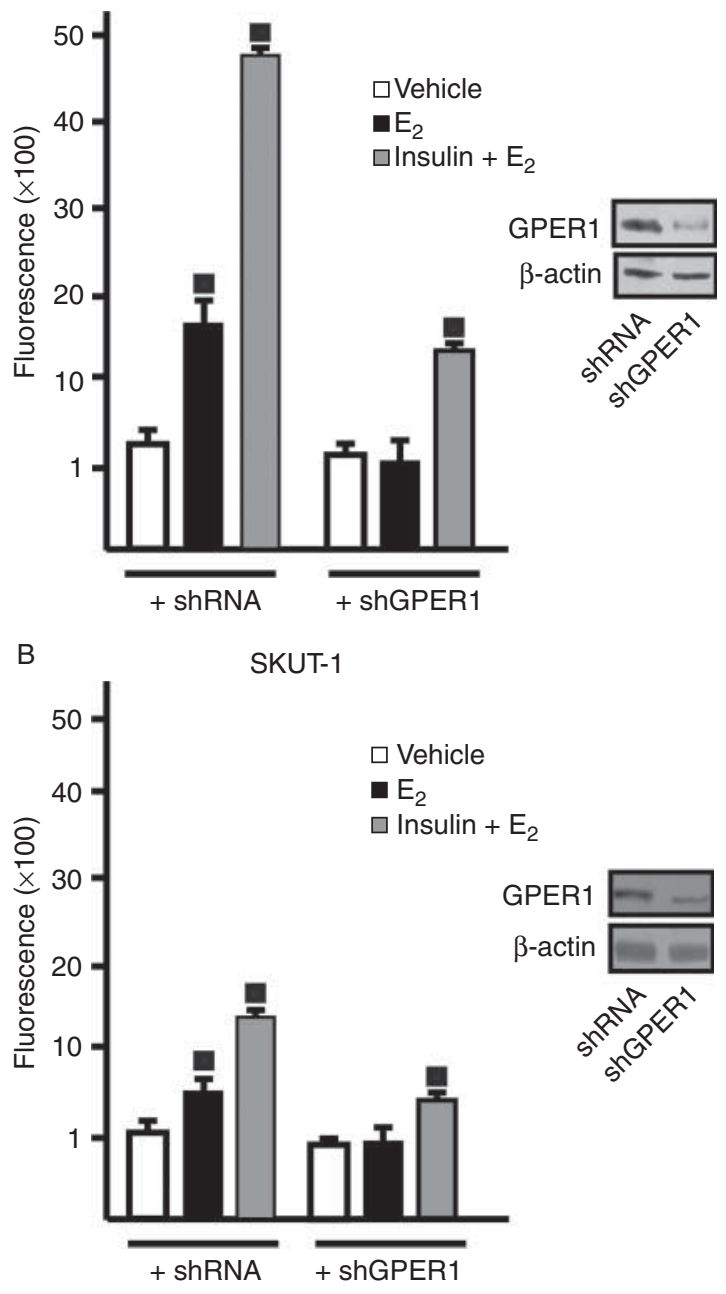

Figure 8

(A and B) CAFs and SKUT-1 cells were transfected with shRNA or shGPER1 and then treated with $10 \mathrm{nM} \mathrm{E} \mathrm{E}_{2}$ for $30 \mathrm{~min}$. Where indicated, cells were treated with $10 \mathrm{nM}$ insulin for $8 \mathrm{~h}$, thereafter the medium was removed and replaced before the treatment for $30 \mathrm{~min}$ with $10 \mathrm{nM} \mathrm{E}$. Each column shows the fluorescence obtained by the measurement of the 2-NBDG uptake and represents the mean \pm s.D. of three independent experiments performed in triplicate. (closed square) $P<0.05$ for cells receiving vehicle vs treatments.

insulin before $\mathrm{E}_{2}$ (Fig. 9). Collectively, these results indicate that insulin potentiates the action of estrogens elicited through GPER1 on glucose uptake and cell-cycle progression.

\section{GPER1 expression in CAFs is positively associated with serum insulin levels}

Previous studies have demonstrated a direct correlation between insulin levels and the occurrence of diverse malignancies (Belfiore \& Malaguarnera 2011). Also, GPER1 expression has been associated with negative biological features in patients with various types of tumors (Prossnitz \& Barton 2011, Sjöström et al. 2014). Interestingly, we found a positive relationship between the insulin levels and the mRNA expression of GPER1 in CAFs obtained from breast cancer patients (Fig. 10), indicating that GPER1 may be regulated in vivo by insulin, at least in the main players of the breast tumor microenvironment, such as CAFs.

\section{Discussion}

Insulin is involved in the regulation of carbohydrate, lipid, and protein metabolism; however, it also exerts a stimulatory role in cancer progression, in particular upon pathophysiological conditions characterized by insulin resistance (Belfiore \& Malaguarnera 2011). In accordance with this, previous experimental and epidemiological studies have demonstrated a positive correlation between insulin levels and cancer development (Belfiore \& Malaguarnera 2011). As regards breast cancer, the potential of insulin to contribute to tumor progression has been highlighted in diverse investigations (Rose \& Vona-Davis 2012, Sieri et al. 2012, Catsburg et al. 2014). Nicely supporting these data, in postmenopausal women within the framework of the Women's Health Initiative Observational Study (WHI-OS), the highest tertile of baseline insulin was associated with a twofold risk increase in breast cancer compared with the lowest tertile (Kabat et al. 2009). Estrogens perform a fundamental role in hormone-sensitive breast cancer, mainly activating the classical ERs (Hall et al. 2001). In addition, the stimulatory effects of estrogens may be mediated through GPER1, which activates a network of transduction pathways triggering diverse biological responses (Prossnitz \& Maggiolini 2009, Prossnitz \& Barton 2014, Scaling et al. 2014).

Considering the well-known functional cross-talk between insulin and estrogen signaling, in the current study we evaluated whether insulin could regulate the expression and function of GPER1 in cancer progression. Using as model systems, the INSR-positive CAFs and leiomyosarcoma cells (SKUT-1), we have demonstrated that insulin transactivates the promoter of GPER1 and upregulates its expression at both the mRNA and protein levels. In particular, we have shown that the induction of GPER1 by insulin is mediated by the rapid activation of PRKCD and MAPK1/2 signal transduction and the stimulation of c-Fos, which is recruited to the AP1 site located within the promoter sequence of GPER1.

Published by Bioscientifica Ltd. 

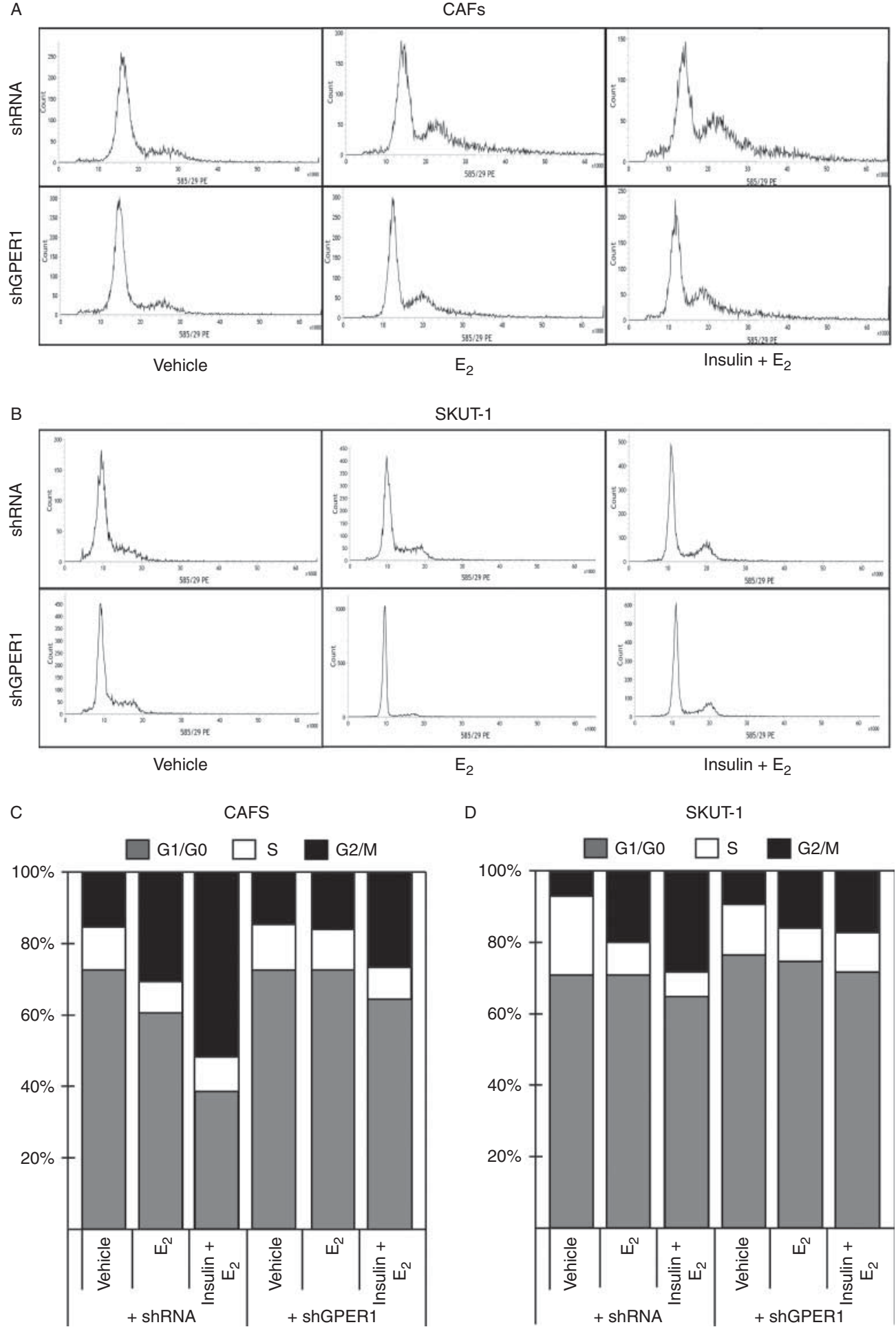

D

SKUT-1

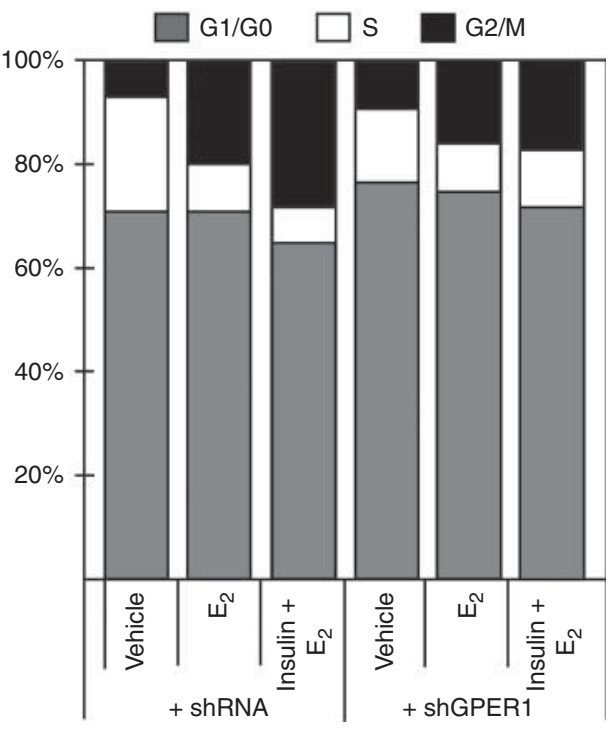

Figure 9

(A and B) Cell-cycle analysis performed in CAFs and SKUT-1 cells transfected with shRNA or shGPER1 and then treated for $8 \mathrm{~h}$ with $10 \mathrm{nM} \mathrm{E}_{2}$. The cells were also treated with $10 \mathrm{nM}$ insulin for $8 \mathrm{~h}$ before the treatment for an additional $8 \mathrm{~h}$ with $10 \mathrm{nM} \mathrm{E}_{2}$, as indicated. (C and D) The histograms show

the percentages of cells in $\mathrm{G} 1 / \mathrm{G} 0$, $\mathrm{S}$, and G2/M phases of the cell cycle, as determined by flow cytometry analysis (BD, FACS JAZZ, Milan, Italy). Values represent the mean \pm s.D. of three independent experiments. 

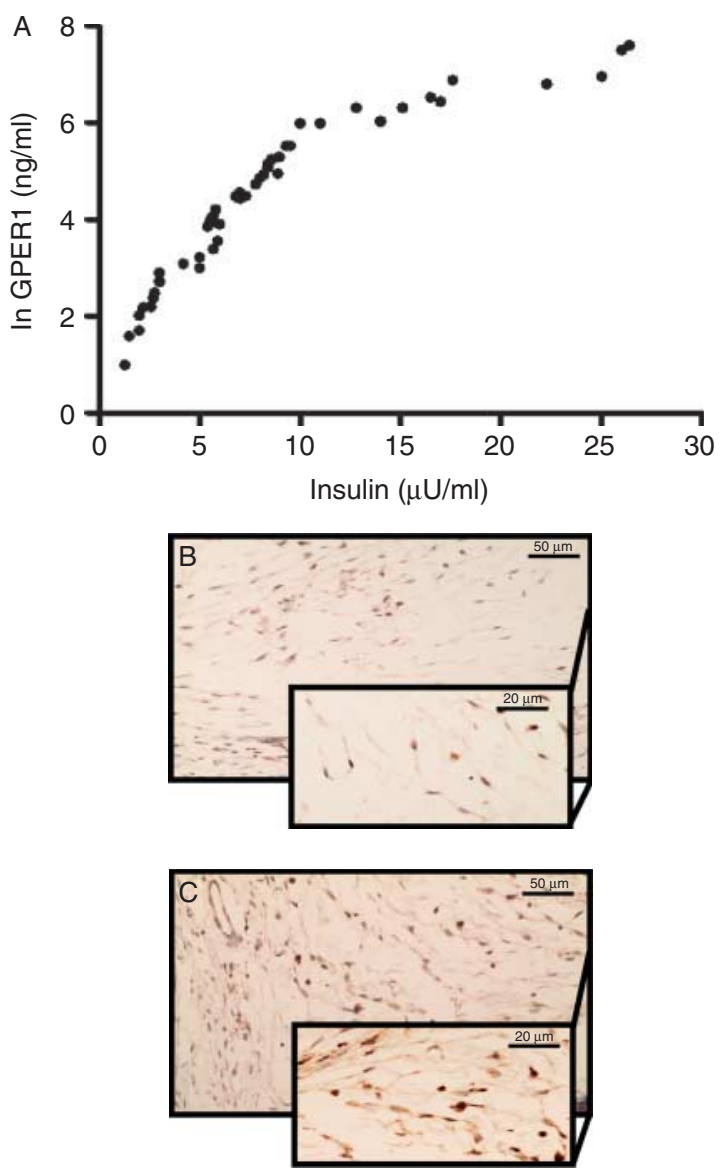

\section{Figure 10}

(A) Correlation between serum insulin levels $(\mu \mathrm{U} / \mathrm{ml})$ and log transformed GPER1 mRNA expression $(\mathrm{ng} / \mathrm{ml})$ determined by real-time PCR in CAFs obtained from breast cancer patients $(n=47 ; r=0.83, P<0.001)$. Representative images of GPER 1 expression in stromal fibroblasts of a breast cancer patient with low serum insulin levels (B) and a breast cancer patient with high serum insulin levels (C). Higher magnification images of specific areas are shown below the original images.

Moreover, we ascertained that the functional role performed by AP1 is essential, as the promoter transactivation as well as the expression of GPER1 were abrogated using a construct encoding a dominant-negative form of c-Fos. Noteworthily, GPER1 and one of its main target genes, $C T G F$, were required for cell migration induced by insulin. As CTGF has been mainly involved in cell motility (Chu et al. 2008, Pandey et al. 2009), the GPER1/CTGF signaling activated by insulin might contribute to the invasion abilities of cancer cells during cancer development and metastasis.

Results from previous studies have indicated that estrogens increase insulin sensitivity and stimulate glucose uptake upon acute and chronic exposure to these steroids in target tissues as well as in ESR1-positive breast cancer cells (Alonso et al. 2006, Moreno et al. 2010, Garrido et al. 2013). On the basis of these findings and considering that GPER1 has been shown to be involved in insulinregulated metabolic functions in both mice and humans (Mårtensson et al. 2009, Kumar et al. 2011, Sharma \& Prossnitz 2013), we have also ascertained that GPER1 mediates the glucose uptake induced by estrogens in CAFs and SKUT-1 cells. When these cells were treated with insulin before $E_{2}$, the glucose uptake was further boosted consequently to the upregulation of GPER1 triggered by insulin, given that this response was abrogated by silencing GPER1 expression. Paralleling the aforementioned results, treatment with insulin before $\mathrm{E}_{2}$ increased the percentage of cells in the G2/M phase, whereas after knocking-down the expression of GPER1 the effects of $\mathrm{E}_{2}$ were no longer evident. We found a positive relationship between the levels of insulin and the expression of GPER1 in CAFs obtained from breast cancer patients, indicating that insulin may regulate GPER1 in vivo. It would be worthwhile to assess in future in vivo studies if insulin may act through regulating GPER1 under different pathophysiological conditions.

The interaction between various G-protein-coupled receptors (GPCRs) and growth factor receptors has become increasingly evident in cancer growth, angiogenesis, and metastasis (Lappano \& Maggiolini 2012). Moreover, experimental, epidemiological, and clinical data indicate that a cross-talk between different GPCRs and insulin signaling plays a critical role in the regulation of normal physiological functions as well as in the pathogenesis of a variety of abnormal processes, including cancer (Kisfalvi et al. 2007, Young \& Rozengurt 2010). In this regard, the current study further highlights the stimulatory role of insulin in tumor progression elicited through the upregulation of GPER1, which consequently strengthens the action of estrogens. Noteworthily, the functional interaction between GPER1 and insulin signaling has been recently extended to the potential of GPER1 to facilitate the metabolic functions of insulin (Prossnitz \& Barton 2014). In accordance with these findings, GPER1-deficient mice displayed a reduced estrogen-stimulated release of insulin in vitro as well as a decreased response to glucose challenges in vivo (Martenson et al. 2009, Kumar et al. 2011). In addition, ligand-activated GPER1 protected $\beta$-cells from apoptosis in mouse and human islets, thus GPER1 may play a functional role in insulin secretion as well as in $\beta$-cell survival (Liu et al. 2009, Prossnitz \& Barton 2014).

In our previous studies, we have highlighted the upregulation of GPER1 expression induced by growth factors such as EGF and IGF1, as well as by one main factor

Published by Bioscientifica Ltd. 
involved in tumor aggressiveness such as hypoxia, in the proliferation and migration of breast cancer cells and CAFs (Albanito et al. 2008, Vivacqua et al. 2009, Recchia et al. 2011, De Francesco et al. 2013, 2014, De Marco et al. 2013). Likewise, estrogens have been shown to stimulate growth effects in tamoxifen-resistant breast cancer cells through both an increased expression of GPER1 and the GPER1mediated transactivation of EGFR (Ignatov et al. 2011). Notably, high levels of expression of GPER1 in breast, endometrial, and ovarian tumors have been associated with a higher risk of developing metastatic disease and poor survival rates (Prossnitz \& Barton 2011). High levels of GPER1 were also identified in IBC, an aggressive and commonly hormone-independent form of breast cancer (Arias-Pulido et al. 2010). Recently, the overexpression of GPER1 and its plasma membrane localization have been suggested to be critical events in breast cancer progression, whereas the lack of GPER1 in the plasma membrane was associated with excellent long-term prognosis in ER-positive tamoxifen-treated breast tumors (Sjöström et al. 2014). Therefore, the expression of GPER1 may characterize not only the estrogen sensitivity and the response to endocrine pharmacological intervention in these tumors, but could also be predictive of biologically aggressive phenotypes consistent with an adverse outcome and low survival. Further supporting the involvement of GPER1 in breast cancer progression, its activation led to certain deformations of breast glandular structure, which characterize the malignant transformation of the breast tissue (Marchese \& Silva 2012). GPER1-dependent proliferation of nontumorigenic breast epithelial cells was also recently assessed, indicating a role for GPER1 in breast physiology and pathology (Scaling et al. 2014).

The present study extends our knowledge regarding the functional interaction between insulin and GPER1 transduction pathways. In this regard, it should be pointed out that in cancer patients affected by insulin resistance, increased insulin levels combine with frequent INSR overexpression leading to abnormal stimulation of nonmetabolic effects mediated by INSR, such as cell survival, proliferation, and migration (Belfiore \& Malaguarnera 2011). For instance, high insulin levels have been associated with an increased risk of breast cancer and breast cancer relapses in diabetic and nondiabetic women (Duggan et al. 2011, Cohen \& Le Roith 2012, Sieri et al. 2012). Taking into account these data and the results of the present study, it would be interesting to evaluate in future studies the actual role performed by estrogenic GPER1 signaling in different pathophysiological conditions characterized by insulin resistance. Altogether, our findings provide novel insights into the potential of GPER1 to contribute to the intricate tumorigenic transduction network triggered by insulin not only in cancer cells but also through the major cells in the tumor microenvironment such as CAFs.

\section{Supplementary data}

This is linked to the online version of the paper at http://dx.doi.org/10.1530/ ERC-14-0245.

Declaration of interest

The authors declare that there is no conflict of interest that could be perceived as prejudicing the impartiality of the research reported.

\section{Funding}

This work was supported by Associazione Italiana per la Ricerca sul Cancro (AIRC, M Maggiolini: IG grant no. 12849/2012; A Belfiore: IG grant no. 14066/13), AIRC project Calabria 2011-2013 and Fondazione Cassa di Risparmio di Calabria e Lucania (M Maggiolini and A Belfiore), PON01_01078 (A Belfiore) and Ministero della Salute grant no. 67/GR2010-2319511 (R Malaguarnera and M Maggiolini).

\section{References}

Albanito L, Madeo A, Lappano R, Vivacqua A, Rago V, Carpino A, Oprea TI, Prossnitz ER, Musti AM, Andó S et al. 2007 G protein-coupled receptor 30 (GPR30) mediates gene expression changes and growth response to $17 \beta$-estradiol and selective GPR30 ligand G-1 in ovarian cancer cells. Cancer Research 67 1859-1866. (doi:10.1158/0008-5472.CAN-06-2909)

Albanito L, Sisci D, Aquila S, Brunelli E, Vivacqua A, Madeo A, Lappano R, Pandey DP, Picard D, Mauro L et al. 2008 Epidermal growth factor induces $\mathrm{G}$ protein-coupled receptor 30 expression in estrogen receptor-negative breast cancer cells. Endocrinology 8 3799-3808. (doi:10.1210/en.2008-0117)

Alonso A, Fernández R, Moreno M, Ordóñez P, González-Pardo H, Conejo NM, Díaz F \& González C 2006 Positive effects of 17ß-estradiol on insulin sensitivity in aged ovariectomized female rats. Journals of Gerontology. Series A, Biological Sciences and Medical Sciences 61 419-426. (doi:10.1093/gerona/61.5.419)

Arias-Pulido H, Royce M, Gong Y, Joste N, Lomo L, Lee SJ, Chaher N, Verschraegen C, Lara J, Prossnitz ER et al. 2010 GPR30 and estrogen receptor expression: new insights into hormone dependence of inflammatory breast cancer. Breast Cancer Research and Treatment 123 51-58. (doi:10.1007/s10549-009-0631-7)

Balhuizen A, Kumar R, Amisten S, Lundquist I \& Salehi A 2010 Activation of $\mathrm{G}$ protein-coupled receptor 30 modulates hormone secretion and counteracts cytokine-induced apoptosis in pancreatic islets of female mice. Molecular and Cellular Endocrinology 320 16-24. (doi:10.1016/ j.mce.2010.01.030)

Bartella V, De Marco P, Malaguarnera R, Belfiore A \& Maggiolini M 2012 New advances on the functional cross-talk between insulin-like growth factor-I and estrogen signaling in cancer. Cell Signalling 24 1515-1521. (doi:10.1016/j.cellsig.2012.03.012)

Belfiore A 2007 The role of insulin receptor isoforms and hybrid insulin/ IGF-I receptors in human cancer. Current Pharmaceutical Design 13 671-686. (doi:10.2174/138161207780249173) http://erc.endocrinology-journals.org DOI: $10.1530 /$ ERC-14-0245 (c) 2014 Society for Endocrinology Printed in Great Britain 
Belfiore A \& Malaguarnera R 2011 Insulin receptor and cancer. Endocrine-Related Cancer 18 R125-R147. (doi:10.1530/ERC-11-0074)

Catsburg C, Gunter MJ, Chen C, Cote ML, Kabat GC, Nassir R, Tinker L, Wactawski-Wende J, Page DL \& Rohan TE 2014 Insulin, estrogen, inflammatory markers, and risk of benign proliferative breast disease. Cancer Research 74 3248-3258. (doi:10.1158/0008-5472.CAN-13-3514)

Chu CY, Chang CC, Prakash E \& Kuo ML 2008 Connective tissue growth factor (CTGF) and cancer progression. Journal of Biomedical Science $\mathbf{1 5}$ 675-685. (doi:10.1007/s11373-008-9264-9)

Cohen DH \& Le Roith D 2012 Obesity, type 2 diabetes, and cancer: the insulin and IGF connection. Endocrine-Related Cancer 19 F27-F45. (doi:10.1530/ERC-11-0374)

De Francesco EM, Lappano R, Santolla MF, Marsico S, Caruso A \& Maggiolini M 2013 HIF-1 $\alpha /$ GPER signaling mediates the expression of VEGF induced by hypoxia in breast cancer associated fibroblasts (CAFs). Breast Cancer Research 4 R64. (doi:10.1186/bcr3458)

De Francesco EM, Pellegrino M, Santolla MF, Lappano R, Ricchio E, Abonante S \& Maggiolini M 2014 GPER mediates activation of HIF-1 $\alpha$ /VEGF signaling by estrogens. Cancer Research 74 1-12. (doi:10. 1158/0008-5472.CAN-13-3590)

De Marco P, Bartella V, Vivacqua A, Lappano R, Santolla MF, Morcavallo A, Pezzi V, Belfiore A \& Maggiolini M 2013 Insulin-like growth factor-I regulates GPER expression and function in cancer cells. Oncogene 6 678-688. (doi:10.1038/onc.2012.97)

Dennis MK, Field AS, Burai R, Ramesh C, Petrie WK, Bologa CG, Oprea TI, Yamaguchi Y, Hayashi S, Sklar LA et al. 2011 Identification of a GPER/GPR30 antagonist with improved estrogen receptor counterselectivity. Journal of Steroid Biochemistry and Molecular Biology 127 358-366. (doi:10.1016/j.jsbmb.2011.07.002)

Duggan C, Irwin ML, Xiao L, Henderson KD, Smith AW, Baumgartner RN, Baumgartner KB, Bernstein L, Ballard-Barbash R \& McTiernan A 2011 Associations of insulin resistance and adiponectin with mortality in women with breast cancer. Journal of Clinical Oncology 29 32-39. (doi:10.1200/JCO.2009.26.4473)

Frasca F, Pandini G, Scalia P, Sciacca L, Mineo R, Costantino A, Goldfine ID, Belfiore A \& Vigneri R 1999 Insulin receptor isoform A, a newly recognized, high-affinity insulin-like growth factor II receptor in fetal and cancer cells. Molecular and Cellular Biology 19 3278-3288. (doi:10.1210/en.2009-0377)

Garrido P, Morán J, Alonso A, González S \& González C 2013 17ß-estradiol activates glucose uptake via GLUT4 translocation and PI3K/Akt signaling pathway in MCF-7 cells. Endocrinology 154 1979-1989. (doi:10.1210/en.2012-1558)

Hall JM, Couse JF \& Korach KS 2001 The multifaceted mechanisms of estradiol and estrogen receptor signaling. Journal of Biological Chemistry 276 36869-36872. (doi:10.1074/jbc.R100029200)

Hess J, Angel P \& Schorpp-Kistner M 2004 AP-1 subunits: quarrel and harmony among siblings. Journal of Cell Science $1175965-5973$. (doi:10.1242/jcs.01589)

Ignatov A, Ignatov T, Weissenborn C, Eggemann H, Bischoff J, Semczuk A, Roessner A, Costa SD \& Kalinski T 2011 G-protein-coupled estrogen receptor GPR30 and tamoxifen resistance in breast cancer. Breast Cancer Research and Treatment 128 457-466. (doi:10.1007/s10549-011-1584-1)

Kabat GC, Kim M, Caan BJ, Chlebowski RT, Gunter MJ, Ho GY, Rodriguez BL, Shikany JM, Strickler HD, Vitolins MZ et al. 2009 Repeated measures of serum glucose and insulin in relation to postmenopausal breast cancer. International Journal of Cancer $\mathbf{1 2 5}$ 2704-2710. (doi:10.1002/ijc.24609)

Kisfalvi K, Rey O, Young SH, Sinnett-Smith J \& Rozengurt E 2007 Insulin potentiates $\mathrm{Ca}^{2+}$ signaling and phosphatidylinositol 4,5-bisphosphate hydrolysis induced by $\mathrm{Gq}$ protein-coupled receptor agonists through an mTOR-dependent pathway. Endocrinology 148 3246-3257. (doi:10.1210/en.2006-1711)

Kumar R, Balhuizen A, Amisten S, Lundquist I \& Salehi A 2011 Insulinotropic and antidiabetic effects of $17 \beta$-estradiol and the GPR30 agonist G-1 on human pancreatic islets. Endocrinology 152 2568-2579. (doi:10.1210/en.2010-1361)

Lappano R \& Maggiolini M 2012 G protein-coupled receptors: novel targets for drug discovery in cancer. Nature Reviews. Drug Discovery 10 47-60. (doi:10.1038/nrd3320)

Lappano R, Rosano C, Santolla MF, Pupo M, De Francesco EM, De Marco P, Ponassi M, Spallarossa A, Ranise A \& Maggiolini M 2012 Two novel GPER agonists induce gene expression changes and growth effects in cancer cells. Current Cancer Drug Targets 12 531-542. (doi:10.2174/ 156800912800673284)

Lappano R, De Marco P, De Francesco EM, Chimento A, Pezzi V \& Maggiolini M 2013 Cross-talk between GPER and growth factor signaling. Journal of Steroid Biochemistry and Molecular Biology 137 50-56. (doi:10.1016/j.jsbmb.2013.03.005)

Liu S, Le May C, Wong WP, Ward RD, Clegg DJ, Marcelli M, Korach KS \& Mauvais-Jarvis F 2009 Importance of extranuclear estrogen receptor- $\alpha$ and membrane $\mathrm{G}$ protein-coupled estrogen receptor in pancreatic islet survival. Diabetes 58 2292-2302. (doi:10.2337/db09-0257)

Liu S, Kilic G, Meyers MS, Navarro G, Wang Y, Oberholzer J \& Mauvais-Jarvis F 2013 Oestrogens improve human pancreatic islet transplantation in a mouse model of insulin deficient diabetes. Diabetologia 56 370-381. (doi:10.1007/s00125-012-2764-1)

Madeo A \& Maggiolini M 2010 Nuclear alternate estrogen receptor GPR30 mediates $17 \beta$-estradiol-induced gene expression and migration in breast cancer-associated fibroblasts. Cancer Research 70 6036-6046. (doi:10.1158/0008-5472.CAN-10-0408)

Maggiolini M \& Picard D 2010 The unfolding stories of GPR30, a new membrane-bound estrogen receptor. Journal of Endocrinology 204 105-114. (doi:10.1677/JOE-09-0242)

Maggiolini M, Vivacqua A, Fasanella G, Recchia AG, Sisci D, Pezzi V, Montanaro D, Musti AM, Picard D \& Andò S 2004 The G proteincoupled receptor GPR30 mediates c-fos up-regulation by $17 \beta$-estradiol and phytoestrogens in breast cancer cells. Journal of Biological Chemistry 279 27008-27016. (doi:10.1074/jbc.M403588200)

Marchese S \& Silva E 2012 Disruption of 3D MCF-12A breast cell cultures by estrogens - an in vitro model for ER-mediated changes indicative of hormonal carcinogenesis. PLOS ONE 7 e45767. (doi:10.1371/journal. pone.0045767)

Mårtensson UE, Salehi SA, Windahl S, Gomez MF, Swärd K, DaszkiewiczNilsson J, Wendt A, Andersson N, Hellstrand P, Grände PO et al. 2009 Deletion of the $\mathrm{G}$ protein-coupled receptor 30 impairs glucose tolerance, reduces bone growth, increases blood pressure, and eliminates estradiol-stimulated insulin release in female mice. Endocrinology 150 687-698. (doi:10.1210/en.2008-0623)

Mizukami Y 2010 In vivo functions of GPR30/GPER-1, a membrane receptor for estrogen: from discovery to functions in vivo. Endocrine Journal $\mathbf{5 7}$ 101-107. (doi:10.1507/endocrj.K09E-332)

Morcavallo A, Gaspari M, Pandini G, Palummo A, Cuda G, Larsen MR, Vigneri R \& Belfiore A 2011 Research resource: new and diverse substrates for the insulin receptor isoform A revealed by quantitative proteomics after stimulation with IGF-II or insulin. Molecular Endocrinology 25 1456-1468. (doi:10.1210/me.2010-0484)

Moreno M, Ordonez P, Alonso A, Diaz F, Tolivia J \& Gonzalez C 2010 Chronic $17 \beta$-estradiol treatment improves skeletal muscle insulin signaling pathway components in insulin resistance associated with aging. Age 32 1-13. (doi:10.1007/s11357-009-9095-2)

Pandey DP, Lappano R, Albanito L, Madeo A, Maggiolini M \& Picard D 2009 Estrogenic GPR30 signalling induces proliferation and migration of breast cancer cells through CTGF. EMBO Journal 28 523-532. (doi:10.1038/emboj.2008.304)

Pandini G, Frasca F, Mineo R, Sciacca L, Vigneri R \& Belfiore A 2002 Insulin/insulin-like growth factor I hybrid receptors have different biological characteristics depending on the insulin receptor isoform involved. Journal of Biological Chemistry 277 39684-39695. (doi:10.1074/jbc.M202766200) http://erc.endocrinology-journals.org DOI: 10.1530/ERC-14-0245 (c) 2014 Society for Endocrinology Printed in Great Britain 
Prossnitz ER \& Barton M 2011 The G-protein-coupled estrogen receptor GPER in health and disease. Nature Reviews. Endocrinology 7 715-726. (doi:10.1038/nrendo.2011.122)

Prossnitz ER \& Barton M 2014 Estrogen biology: new insights into GPER function and clinical opportunities. Molecular and Cellular Endocrinology 389 71-83. (doi:10.1016/j.mce.2014.02.002)

Prossnitz ER \& Maggiolini M 2009 Mechanisms of estrogen signaling and gene expression via GPR30. Molecular and Cellular Endocrinology 308 32-38. (doi:10.1016/j.mce.2009.03.026)

Pupo M, Pisano A, Lappano R, Santolla MF, De Francesco EM, Abonante S, Rosano C \& Maggiolini M 2012 Bisphenol A induces gene expression changes and proliferative effects through GPER in breast cancer cells and cancer-associated fibroblasts. Environmental Health Perspectives 120 1177-1182. (doi:10.1289/ehp.1104526)

Recchia AG, De Francesco EM, Vivacqua A, Sisci D, Panno ML, Andò S \& Maggiolini M 2011 The G protein-coupled receptor 30 is up-regulated by hypoxia inducible factor- $1 \alpha$ (HIF-1 $\alpha$ ) in breast cancer cells and cardiomyocytes. Journal of Biological Chemistry 286 10773-10782. (doi:10.1074/jbc.M110.172247)

Rosano C, Lappano R, Santolla MF, Ponassi M, Donadini A \& Maggiolini M 2012 Recent advances in the rationale design of GPER ligands. Current Medicinal Chemistry 19 6199-6206. (doi:10.2174/092986712804485755)

Rose DP \& Vona-Davis L 2012 The cellular and molecular mechanisms by which insulin influences breast cancer risk and progression. Endocrine-Related Cancer 19 R225-R241. (doi:10.1530/ERC-12-0203)

Scaling AL, Prossnitz ER \& Hathaway HJ 2014 GPER mediates estrogeninduced signaling and proliferation in human breast epithelial cells and normal and malignant breast. Hormones \& Cancer 3 146-160. (doi:10.1007/s12672-014-0174-1)

Sciacca L, Mineo R, Pandini G, Murabito A, Vigneri R \& Belfiore A 2002 In IGF-I receptor-deficient leiomyosarcoma cells autocrine IGF-II induces cell invasion and protection from apoptosis via the insulin receptor isoform A. Oncogene 21 8240-8250. (doi:10.1038/sj.onc.1206058)

Sell C, Dumeni G, Deveaud C, Miura M, Coppola D, DeAngelis T, Rubin R, Efstratiadis A \& Baserga R 1994 Effect of a null mutation of the insulinlike growth factor I receptor gene on growth and transformation of mouse embryo fibroblasts. Molecular and Cellular Biology 14 3604-3612. (doi:10.1128/MCB.14.6.3604)

Sharma G \& Prossnitz ER 2013 Mechanisms of estradiol-induced insulin secretion by the G protein-coupled estrogen receptor GPR30/GPER in pancreatic $\beta$-cells. Endocrinology 152 3030-3039. (doi:10.1210/en. 2011-0091)

Sharma G, Hu C, Brigman JL, Zhu G, Hathaway HJ \& Prossnitz ER 2013 GPER deficiency in male mice results in insulin resistance, dyslipidemia, and a proinflammatory state. Endocrinology 154 4136-4145. (doi:10.1210/en.2013-1357)

Sieri S, Muti P, Claudia A, Berrino F, Pala V, Grioni S, Abagnato CA, Blandino G, Contiero P, Schunemann HJ et al. 2012 Prospective study on the role of glucose metabolism in breast cancer occurrence. International Journal of Cancer 130 921-929. (doi:10.1002/ijc.26071)

Sjöström M, Hartman L, Grabau D, Fornander T, Malmström P, Nordenskjöld B, Sgroi DC, Skoog L, Stål O, Leeb-Lundberg LM et al. 2014 Lack of G protein-coupled estrogen receptor (GPER) in the plasma membrane is associated with excellent long-term prognosis in breast cancer. Breast Cancer Research and Treatment 145 61-71. (doi:10.1007/ s10549-014-2936-4)

Vigneri P, Frasca F, Sciacca L, Pandini G \& Vigneri R 2009 Diabetes and cancer. Endocrine-Related Cancer 16 1103-1123. (doi:10.1677/ERC-09-0087)

Vivacqua A, Bonofiglio D, Recchia AG, Musti AM, Picard D, Andò S \& Maggiolini M 2006a The G protein-coupled receptor GPR30 mediates the proliferative effects induced by $17 \beta$-estradiol and hydroxytamoxifen in endometrial cancer cells. Molecular Endocrinology 20 631-646. (doi:10.1210/me.2005-0280)

Vivacqua A, Bonofiglio D, Albanito L, Madeo A, Rago V, Carpino A, Musti AM, Picard D, Andò S \& Maggiolini M 2006b 17ß Estradiol, genistein, and 4-hydroxytamoxifen induce the proliferation of thyroid cancer cells through the G protein coupled-receptor GPR30. Molecular Pharmacology 70 1414-1423. (doi:10.1124/mol.106.026344)

Vivacqua A, Lappano R, De Marco P, Sisci D, Aquila S, De Amicis F, Fuqua SA, Andò S \& Maggiolini M 2009 G protein coupled receptor 30 expression is up-regulated by EGF and TGF $\alpha$ in estrogen receptor a-positive cancer cells. Molecular Endocrinology 23 1815-1826. (doi:10.1210/me.2009-0120)

Yamada K, Saito M, Matsuoka H \& Inagaki N 2007 A real-time method of imaging glucose uptake in single, living mammalian cells. Nature Protocols 2 753-762. (doi:10.1038/nprot.2007.76)

Young SH \& Rozengurt E 2010 Crosstalk between insulin receptor and G protein-coupled receptor signaling systems leads to $\mathrm{Ca}^{2+}$ oscillations in pancreatic cancer PANC-1 cells. Biochemical and Biophysical Research Communications 401 154-158. (doi:10.1016/j.bbrc.2010.09.036)

Received in final form 19 June 2014

Accepted 8 July 2014

Made available online as an Accepted Preprint

10 July 2014 http://erc.endocrinology-journals.org

DOI: 10.1530/ERC-14-0245
(C) 2014 Society for Endocrinology Printed in Great Britain
Published by Bioscientifica Ltd. 